УДК 323:316.4

https://doi.org/10.34142/24130060.2019.18.2.02

\title{
МОБІЛЬНІСТЬ І ТРАНСФОРМАЦІЇ ПОЛІТИЧНОЇ СИСТЕМИ ТА СУСПІЛЬСТВА: ТЕОРЕТИЧНИЙ АСПЕКТ
}

\author{
О.О. Безрук \\ Харківський національний педагогічний університет імені Г.С. Сковороди
}

Розглянуто актуальні проблеми дослідження мобільності й трансформацій політичної системи та суспільства на теоретичному рівні. Проаналізовано базові варіанти станів політичної системи як неконсервативної, дисипативної системи. Інтерпретовано основні стани політичної системи, встановлено зв'язки між цими станами. Досліджено типологію аттракторів системи, як детермінант ї̈ розвитку та чиннику кризового стану.

Приділено увагу проблемі демократичного транзиту як окремого варіанту трансформаційних прочесів, наведено механізми його реалізачії. Артикульовано проблему впливу еліт на трансформаційні процеси. Розглянуто проблему перспектив демократизачії на глобальному рівні.

Досліджено аспект мобільності як специфічного набору процесів, щз дозволяють проявлятися різним формам економічного, сочіального та політичного життя.

Ключові слова: політична система, мобільність, демократичний транзит, прочес, політична трансформачія, суспільство, політична стабільність.

\section{МОБИЛЬНОСТЬ И ТРАНСФОРМАЦИИ ПОЛИТИЧЕСКОЙ СИСТЕМЫ И ОБЩЕСТВА: ТЕОРЕТИЧЕСКИЙ АСПЕКТ}

\section{А.А. Безрук}

Рассмотрены актуальные проблемы исследования мобильности и трансформаций политической системы и общества на теоретическом уровне. Проанализировань базовые варианты состояний политической системы как неконсервативной, диссипативной системы. Интерпретировано основные состояния политической системы, установлены связи между этими состояниями. Исследована типология аттракторов системы, как детерминант ее развития и фактора кризисного состояния.

Уделено внимание проблеме демократического транзита как отдельного варианта трансформационных прочессов, приведены механизмы его реализации. Артикулирована проблема влияния элит на трансформационные процессы. Рассмотрена проблема перспектив демократизачии на глобальном уровне.

Исследован аспект мобильности как специфического набора процессов, позволяющих проявляться различным формам экономической, сочиальной и политической жизни.

Ключевые слова: политическая система, мобильность, демократический транзит, процесс, политическая трансформация, общество, политическая стабильность.

(C) О.О. Безрук, 2019 


\section{MOBILITY AND TRANSFORMATION OF THE POLITICAL SYSTEM AND SOCIETY: A THEORETICAL ASPECT}

\section{O. Bezruk}

Actual problems of studying the mobility and transformations of the political system and society at the theoretical level are considered. The basic variants of states of the political system as a non-conservative, dissipative system are analyzed. The basic states of the political system have been interpreted and the relations between these states have been established. Here are some options for solving system crises. The typology of the attractors of the system as a determinant of its development and the factor of crisis state is investigated.

Attention is paid to the problem of democratic transit as a separate variant of transformation processes, mechanisms of its realization are given: legitimation-institutional, procedural-institutional, value-mobilizing, procedural-imitative. It is stated that the coherence of transformation of the political system and society does not always lead to unambiguous results. The problem of elite influence on transformation processes is articulated. It is argued that in the absence of a unified system of political values in society, the opposition is demanding the formation of a new political system. The problem of democratization prospects at the global level is considered. A group of factors that adversely affect the prospects for democracy in individual countries is outlined.

The aspect of mobility as a specific set of processes that allow to manifest different forms of economic, social and political life in the context of the issue of adaptation to changes is investigated. The basic levels of implementation of a successful adaptation result: external and internal are studied and analyzed. It is argued that the activation of mobility processes in modern societies is destroying the adaptation mechanisms that have taken place in traditional societies.

Keywords: political system, mobility, democratic transit, process, political transformation, society, political stability.

Постановка проблеми. Збереження та забезпечення штатного функціонування політичної системи виступає фундаментальною основою «живучості» сучасної держави. Особливої значущості дана проблема набирає в наш час. Глобалізаційні загрози національному суверенітету, криза міжнародного права, зростання кількості недержавних акторів та їхнього впливу на політичні процеси, загальна турбулентність світового політичного устрою - все це формує зовнішні та внутрішні виклики існуючим політичним системам. Така ситуація актуалізує низку запитань, що стосуються конкретних дій, які б забезпечили виживання системи в конкретних складних умовах. Особливе місце серед них займають проблеми мобільності та трансформації.

Аналіз актуальних досліджень. Окремі аспекти процесу мобільності розглянуто в роботах П. Сорокіна, 3. Баумана, П. Вірільйо, Д. Лоу, 
С. Ліпсета, Р. Дарендорфа, В. Парсонса, Д. Уррі, А. Обершала, Ю. Качанова, В. Амєліна, М. Пінчука, А. Круталевич, В. Попова та інших.

Концептуальні розробки з проблем політичних трансформацій наявні в роботах Д. Растоу, А. Пшеворського, Ф. Шміттера, Х. Лінца, Г. О’Доннела, К. Оффе, Т. Кузьо, О. Романюка, В. Полохала, О. Куценко, А. Гілєва, Г. Агєєва та низки інших науковців.

Метою статті є теоретичний аналіз проблем трансформації політичної системи й суспільства за умов сучасних викликів та чиннику мобільності в межах окресленої проблеми.

Виклад основного матеріалу. Функціонування політичних систем, як окремого різновиду систем, пов’язане з низкою станів, що можуть виникати внаслідок тих або інших чинників. Описати ці стани можна в категоріях «стабільність», «катастрофа», «трансформація», «розпад».

Слід звернути увагу на питання демаркації понять «політична стабільність» й «стабільність політичної системи», і чи є необхідність такої демаркації?

Політична стабільність описується як ситуація, при якій відсутні осередки внутрішніх конфліктних ситуацій, а також відсутня агресивна насильницька поведінка в суспільстві при зміні влади. Такий стабільний державний устрій розглядається в якості мирного, законослухняного суспільства, де процес прийняття рішень і політико-економіко-соціальні зміни $€$ результатом інституціалізованих процедур, а не результатом вирішених питань і проблем шляхом застосування насильства (Билюга, 2018).

Виділяють циклічний процес зміни стадій політичної стабільності, які можна звести до наступного:

* перший етап - для цього циклу характерно досягнення рівноваги;

* другий етап - відбувається дестабілізація;

* третій етап - втрата рівноваги; 
* четвертий етап - досягнення нової рівноваги (Билюга, 2018).

Виходячи з вищенаведеного, слід зауважити, що категорія «політична стабільність» описує певний стан політичної системи та суспільства в цілому, як деяку результуючу діяльності першої.

Що стосується «стабільності політичної системи», то в даному випадку мова йде про виключно «штатне» функціонування політичної системи, як «чорної скриньки» окремо від взаємозв’язку із суспільством; як автономної одиниці.

Під поняттям «катастрофи системи» розуміють «стрибкоподібні зміни, що виникають у вигляді раптової відповіді системи на плавну зміну зовнішніх умов» (Арнольд, 1990, с. 8).

Таким чином, «катастрофа» $\epsilon$ окремим випадком трансформації. Очевидно, що процеси трансформації системи можуть призводити як до відновлення стабільності, так і до стану розпаду. О. Романюк зазначає, що «поняття «трансформація» акцентує увагу на якісних перетвореннях, яких суспільний організм зазнає у процесі переходу (перетворення якості А на якість В)» (Требін ред., 2015, с. 735).

Системи, які взаємодіють 3 навколишнім середовищем визначаються як неконсервативні. Якщо неконсервативна система в ході взаємодії віддає енергію в навколишнє середовище, то іiі ідентифікують як дисипативну. Політичні системи відносяться саме до таких типів систем.

Параметри стану даних систем визначаються аттракторами. Незалежно від типу неконсервативної дисипативної системи, виокремлюють чотири типи аттракторів.

Перший тип - «точковий аттрактор». Він відповідає сталому режиму, коли параметри динамічної системи не змінюються 3 часом, i кожен 3 параметрів описується точкою.

Другий тип - «циклічний (періодичний) аттрактор». Після закінчення перехідного процесу система приходить в коливальний режим. Коливання 
(цикли) можуть мати складну форму, але все одно система періодично повертається в точку початку циклу і цикл повторюється. Відповідно, параметри системи також циклічно змінюють свої значення.

Третій тип - «квазіперіодичнийй аттрактор». Такий тип аттрактора іноді виникає тільки в системах, описуваних не менше ніж трьома параметрами.

Четвертий тип - «дивний аттрактор». Детермінована система поводиться хаотичним чином. Знаючи положення системи, в якийсь момент часу, ми не можемо точно передбачити, де буде система через досить великий проміжок часу. Дивний атрактор складається 3 нескінченної кількості точок, розташованих в замкнутій області, але жодна з точок не стикається 3 іншою. За дивним аттрактором система поводиться хаотично, але не безладно - все відбувається в конкретній замкнутій області. Відтворити поведінку системи в дивному аттракторі неможливо (Полунин и Тимофеев, 2009, с. 31-32).

Найменш прогнозованим та найбільш ризикованим для системи є іï залучення до останнього типу аттрактора, що може призвести до кризового стану.

Існують три варіанти розв’язання кризи системи:

1) розпад або загибель системи, при цьому іï елементи захоплюються іншими системами;

2) реформа - поступова перебудова ядра, генотипу системи, що веде до появи якісно нової системи;

3) революція - різка, стрибкоподібна зміна ядра системи, катастрофічний перехід з одного стану в інший (Плотинский, 2001, с. 192).

Останні два типи символізують трансформацію та катастрофу політичної системи. Трансформація в цьому контексті пов’язана $з$ процесом демократичного транзиту, як принципово новим типом політичної модернізації, що реалізується через наступні механізми: 
Легітимаційно-інституційний - передбачає еволюційний розвиток демократичної політичної культури суспільства, за настання домінування якої "знизу" відбувається інституціоналізація демократичних інститутів влади як формалізованим (прийняття Конституції США), так і неформальним (неписані правила політичної діяльності у Великій Британії) методом.

Процедурно-інституційний - виступає у формі конституційної інженерії, коли рушійною силою державно-владних перетворень є сильна політична воля харизматичного державця та раціонально-логічний стратегічний план інституційної перебудови владних органів за середнього рівня мобілізації населення, але високого рівня мобілізації фінансових, інтелектуальних, організаційно-політичних тощо ресурсів держави.

Ціннісно-мобілізуючий - виступає у формі національної ідеї, коли рушійною силою демократичного реформування виступає палка віра в кращий державний устрій та бажання докласти зусиль до його наближення за високого рівня мобілізації суспільства.

Процедурно-імімаційний - формально запроваджувані цілком демократичні інституції наповнюються невластивими для демократичного суспільства пост авторитарними ментально-владними відносинами за майже повної відстороненості суспільства, мінімальної (нерідко - переважно протестної) політичної участі громадян (Дзюндзюк, Котуков та Радченко, 2011, c. 32-34).

Дослідження ефективності транзиту потребує вироблення чітких критеріїв, використання яких надавало б чітку траєкторію пройденої трансформації. В цьому сенсі необхідно згенерувати уніфікований набір параметрів, але навряд чи даний набір буде носити імперативний характер, позаяк глобалізаційні впливи суттєво коректують умови та інформаційний контекст.

У циркулюючих моделях трансформації політичної системи, які заслуговують на серйозний розгляд, значну, якщо не виняткову, увагу приділяють виборам до органів влади, відповідності їх результатів 
волевиявлення громадян, функціонуванню партій, гарантіям належного представництва різних груп інтересів, запобігання зловживань при організації виборчого процесу. Це, безумовно, виправдано і заслуговує на всіляку підтримку. Однак, констатуючи це, не слід забувати, що вибори, як i міжпартійні ігри, - лише верхній, найбільш помітний шар розглянутої проблеми. Існують й інші, глибинні шари. Зазвичай в ході дискусій розмова про них не ведеться. Тим часом, без їх перетворення повне оздоровлення політичної системи практично неможливо (Галкин, 2010).

Когерентність трансформації політичної системи та суспільства не завжди призводить до однозначних результатів. На цей феномен вже звертали увагу класики транзитології. Крах деспотичного режиму не означає автоматичного встановлення відкритого суспільства. Відкрите суспільство не зводиться до відсутності державного втручання і тиранії. Це дуже складна, найтонша структура, i щоб створити іiі, необхідні свідомі зусилля (Библиотека Гумер, 1997).

Окремим аспектом трансформації політичної системи виступає питання циркуляції еліт та їі здатності до створення умов пакту. При цьому слід враховувати, що вразливе місце жорсткої владної вертикалі - кадрова селекція. Визначальне значення для підбору і висування працівників купують не професіоналізм і кваліфікація, не здатності і моральні якості, а особиста відданість, догідливість і беззаперечна, нехай навіть уявна, старанність. Знижується мобільність кадрів, відбувається свого роду закупорка кровоносних судин управлінського апарату. Все це утворює поживне середовище для самовладдя на всіх рівнях адміністративного управління i створює сприятливі умови для корупції, паралізуючої дії державного механізму (Галкин, 2010).

У тому випадку, якщо єдина система політичних цінностей в суспільстві не сформувалася, опозиція критикує панівну частину політичного класу 3 точки зору неприйнятності сформованих політичних інститутів, виступає з вимогою формування нової політичної системи. У цьому випадку 
особливу роль в процесі функціонування і відтворення політичного класу починають грати не тільки економічно панівні соціальні верстви, а й групи, що мають вплив в інших соціальних сферах. В результаті боротьби несумісних один 3 одним частин політичного класу відбувається його дезінтеграція і посилення політичної нестабільності в суспільстві. В результаті здійснюється політична мобільність, оскільки вибули члени політичного класу потребують заміщення. Соціальні спільності знову висувають своїх представників і делегують їм повноваження.

Аналізуючи проблеми трансформації політичної системи та суспільства не можна не враховувати чинник демократизації в глобальному ракурсі. Окремі суперечності демократичного розвитку на початку XXI ст. викликають певний скепсис стосовно подальшого розповсюдження демократії. Л. Даймонд вказує, що сам розмах третьої хвилі може створити похмурі перспективи для четвертої. Майже всі країни, які мали сприятливі економічні, соціальні і культурні умови для виникнення демократії, демократизувалися. Більшість тих країн, які не зазнали демократизацію, не виглядають багатообіцяючими кандидатами на демократичний перехід протягом одного або двох наступних десятиліть. У декількох 3 найбільш репресивних країн світу, особливо в Іраку, Сирії, Лівї, Північній Кореї та на Кубі, здійснення навіть помірної політичної лібералізації, ймовірно, зажадає смерті або повалення довгі роки правили там тиранів або їхніх клік. Якщо не брати до уваги Кувейт, то багаті нафтою монархії Перської затоки на чолі 3 Саудівською Аравією поки проявили мало схильності до будь-якої політичної відкритості.

Для більшої частини 3 тих 53 держав, які оцінюються групою експертів-спостерігачів 3 «Freedom House» в якості «не-вільних», перспективи для демократизації найближчим часом здаються мало обнадійливими. До 49 ц цих держав може бути застосована одна або більше 3 трьох наступних характеристик (до багатьох 3 них застосовні дві, а до кількох і все три): 
* перевага мусульманського населення i часто наявність сильного тиску з боку ісламського фундаменталізму;

* глибокі етнічні розколи при відсутності якоїсь однієї домінуючою етнічної групи, до якої б належало більше двох третин населення;

* наявність неокомуністичних або посткомуністичних режимів 3 сильними пережитками розгалуженого однопартійного домінування.

* крім того, «невільні» держави $є$ непропорційно бідними (Библиотека Гумер, 1999).

I тим не менше діапазон внутрішніх структур дійсно передбачуваним чином різниться в залежності від суспільств. Ключовим фактором розвитку в рамках природної держави є спільна еволюція інституційних опор для організацій, що знаходяться як всередині, так і зовні формальної структури уряду (Норт, Уоллис и Вайнгаст, 2011, с. 447).

Подальший аналіз трансформацій потребує додаткової уваги до такого значущого процесу як мобільність. Мобільність являє собою певний набір процесів, які дозволяють проявлятися різним формам економічного, соціального та політичного життя (Урpi, 2012). Адаптивний аспект мобільності в межах системи взаємодій висвітлює такі специфічні феномени соціально-політичного порядку, як конфлікт та конкуренція. Соціальнополітичний порядок припускає конфлікт, у який переростає конкуренція по ходу адаптивної діяльності індивіда. Конфлікт є усвідомленим і приймається необхідним у конкретних умовах. Конфлікт як правило виникає через невідповідність інтересів і зазіхань іншого / інших на певні сфери життєдіяльності індивіда. Здатність відстояти сфери впливу й вчасно проявляти агресію властиві окремим групам й підвищують їхні адаптивні можливості. Конфлікт - це своєрідна фаза перевірки адаптивних механізмів діючого суб’єкта. Соціально-політичний порядок має на меті захистити 
економічні інтереси особистості / групи, у той же час будучи наслідком економічного порядку.

Слід зазначити, що спонукання індивідів / груп до певних дій, які активізують процеси мобільності є стимулюючою складовою. Стимулом, наприклад, політичної мобільності стають привілеї, які відокремлюють політичних представників від інших спільнот, але так чи інакше на неї впливає низка факторів, частка яких є незалежними від політика, а інша - $€$ результатом його діяльності.

Здатності людини або групи до адаптації (біологічної або соціальної)

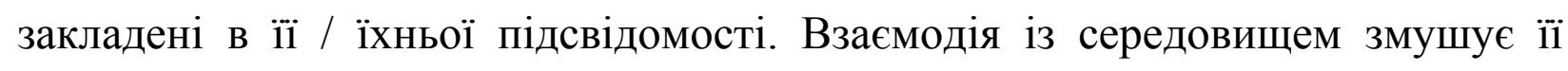
активізувати ці здібності, тому що в іншому випадку зростає ймовірність деструктивного розв’язання ситуації і виникнення труднощів при освоєнні дійсності. Успішний результат соціальної адаптації має два рівні реалізації:

1. Зовнішній. Індивід / група займають відносно стабільне місце в соціальній структурі соціуму, налагоджує канали взаємодії з оточуючими, бере участь у виробництві й розподілі економічних, політичних, культурних, фінансових та інших ресурсів; а дії отримують соціальне схвалення.

2. Внутрішній. Індивід / група відчувають конкретний результат від власної діяльності, свого оточення, наповнюють сенсом (в його баченні) означену діяльність, актуалізують цінності, що сформовані суспільством; вони внутрішньо підготовлені до трансформацій, а їхні ментальні структури здатні приймати оперативні рішення i прогнозувати розвиток наявних ситуацій.

Дезадаптація має кардинально протилежні характеристики. Ззовні це проявляється у вигляді невизначеності (маргінальності) соціального статусу, фінансово-економічних негараздів; руйнування каналів взаємодії 3 оточенням, громадського осуду індивіду за будь-які дії або відсутність таких; застосування каральних санкцій, виключення і відсторонення індивіда від суспільного життя. Така ситуація провокує розвиток деструктивних процесів на внутрішньо особистісному / внутрішньогруповому рівнях або може бути 
їх наслідком. Погіршується соціальне самопочуття індивіда, він відчуває внутрішній дискомфорт, який може набути рис різнорівневого конфлікту; мотивація до активізації діяльності щодо поліпшення власного становища дезактуалізіується, ментальні структури провокують виникнення депресивних ментальних форм про безглуздість існування; індивід втрачає здатність адекватно реагувати на мінливу дійсність, концентруючись на негативних установках.

Активізація процесів мобільності в сучасних суспільствах руйнує механізми адаптації, які діяли в суспільствах традиційного типу. Це проявляється в атомізації соціуму, послабленні впливу традиційних інститутів на особистість, їі перебуванню в ціннісному вакуумі й т. ін.. Тому, подальші дослідження 3 проблеми адаптації мають бути направлені на вироблення механізмів гальмування цих деструктивних процесів.

Висновки та перспективи подальших досліджень. Трансформаційні процеси, які зачіпають політичні системи та суспільство суттєво впливають на визначення порядку денного, тому прогнозування їхнього розвитку залишається актуальним завданням для експертного співтовариства. Зменшення міри ентропії в соціально-політичних відносинах сприятиме реалізації концепції стійкого розвитку, позаяк світ стає більш складним, жорстким, мобільнішим та менше передбачуваним, а світова політична система визначається властивостями «дивного» аттрактора.

\section{ЛІТЕРАТУРА}

1. Арнольд, В. 1990. Теория катастроф. Москва: Наука. Гл. ред. физ. мат. лит.

2. Библиотека Гумер, 1997. Сорос Д. Капиталистическая угроза. [онлайн]. Доступно: https://www.gumer.info/bibliotek_Buks/Polit/Article/sor_kapugr.php [Дата обращения 24 Январь 2019]

3. Библиотека Гумер, 1999. Даймонд Л. Глобальная перспектива. [онлайн] Доступно: https://www.gumer.info/bibliotek_Buks/Polit/Article/daym_glob.php [Дата обращения 24 Январь 2019]

4. Билюга, С., 2018. Политическая стабильность: основные подходы $\kappa$ анализу устойчивости политических систем. [онлайн] Доступно: http://www.intelros.ru/readroom/vek-globalizacii/ek2-2018/35909-politicheskaya- 
stabilnost-osnovnye-podhody-k-analizu-ustoychivosti-politicheskih-sistem.html [Дата обращения 28 Январь 2019]

5. Галкин, А., 2010. Раздумья о трансформации политической системы. Власть. [онлайн] 6, с. 4-12. Доступно: https://cyberleninka.ru/article/n/razdumya-otransformatsii-politicheskoy-sistemy/viewer. [Дата обращения 28 Январь 2019]

6. Дзюндзюк, В. Б., Котуков О. А., Радченко О. В., 2011. Політична модернізачія: теорія та історія. Київ: НАДУ.

7. Норт, Д., Уоллис, Д. и Вайнгаст, Б. 2011. Насилие и сочииальныле порядки. Конщептуальные рамки для интерпретации письменной истории человечества. Москва: Изд. Института Гайдара.

8. Плотинский, Ю. М. 2001. Модели социальных процессов. Москва: Логос.

9. Полунин, Ю. А. и Тимофеев, И. Н. 2009. Нелинейные политические процессы. Москва: МГИМО.

10. Требін, М. П. ред., 2015. Політологічний енциклопедичний словник. Харків: Право.

11. Урри, Дж. 2012. Мобильности. Москва: «Праксис».

\section{Інформація про автора}

Безрук Олександр Олександрович - кандидат політичних наук, доцент, завідувач кафедри політології, соціології і культурології Харківського національного педагогічного університету імені Г.С. Сковороди; e-mail: alex.bezruk@ukr.net; ORCID: http://orcid.org/0000-0002-4963-5707.

Стаття надійшла до редакції: 25.02.2019 р. Прийнята до друку: 05.03.2019 р. 